\title{
Persisting Haemophilus influenzae strains induce lower levels of interleukin-6 and interleukin-8 in H292 lung epithelial cells than nonpersisting strains
}

\author{
P. Bresser*+, L. van Alphen**, F.J.M. Habets*+, A.A.M. Hart ${ }^{++}$, J. Dankert**, \\ H.M. Jansen*, R. Lutter*+
}

Persisting Haemophilus influenzae strains induce lower levels of interleukin-6 and interleukin-8 in H292 lung epithelial cells than nonpersisting strains. P. Bresser, L. van Alphen, F.J.M. Habets, A.A.M. Hart, J. Dankert, H.M. Jansen, R. Lutter. @ERS Journals Ltd 1997.

ABSTRACT: Nonencapsulated Haemophilus influenzae strains isolated from patients with chronic bronchitis can be divided into those that persist in the lower respiratory tract and those that do not. We tested the hypothesis that persisting and nonpersisting strains differ in the extent to which they activate epithelial cells to produce two potent inflammatory mediators, interleukin (IL)-6 and IL-8.

A suspension of $10^{7}$ and $10^{8}$ colony forming units (cfu) $\cdot \mathrm{mL}^{-1}$ of $\mathrm{H}$. influenzae, persisting and nonpersisting, induced a dose- and time-dependent production of IL-6 and IL-8 by the human pulmonary mucoepidermoid carcinoma-derived cell line $\mathbf{H 2 9 2}$, but levels of IL-6 were lower after exposure to persisting $\boldsymbol{H}$. influenzae $(p<0.05)$. IL-8 production showed a similar trend ( $p<0.02$; analysis of variance). $H$. influenzae bacteria that adhered to $\mathrm{H} 292$ cells were equally distributed over persisting and nonpersisting isolates and induced IL-6 and IL-8 levels similar to their nonadhering counterparts. The difference between persisting and nonpersisting $H$. influenzae was not due to cytotoxic, antimetabolic or antiproliferative effects on $\mathrm{H} 292$ cells. Furthermore, pre-exposure of cells to persisting and nonpersisting isolates did not block subsequent IL-1 $\beta$-induced IL-6 production.

We conclude that persisting clinical isolates induce less interleukin-6 and interleukin-8 in $\mathbf{H 2 9 2}$ cells than nonpersisting isolates, probably because they excrete lower amounts of a stimulus of $\mathrm{H} 292$ cells. The stimulus is heat stable, hydrophilic and nonproteinous and probably not lipopolysaccharide alone. These findings support the suggestion that some strains of Haemophilus influenzae that persist in the airways of patients, may do so because they induce only a weak inflammatory response.

Eur Respir J 1997; 10: 2319-2326.
*Dept of Pulmonology, +Clinical and Laboratory Immunology Unit, **Dept of Medical Microbiology, and ${ }^{++}$Dept of Clinical Epidemiology and Biostatistics, Academic Medical Center, University of Amsterdam, PO Box 22700, 1100 DE Amsterdam, The Netherlands

Correspondence: R. Lutter

Dept of Pulmonology F4-208

Academic Medical Center

Meibergdreef 9

1105 AZ Amsterdam

The Netherlands

Keywords: Airway epithelium chronic bronchitis

Haemophilus influenzae inflammatory mediators

Received: October 211996

Accepted after revision July 81997

These studies were partly funded by Astra Pharmaceutica BV (Rijswijk, The Netherlands).
Nonencapsulated Haemophilus influenzae are, either intermittently or continuously, isolated from sputum samples of a majority of patients with chronic obstructive pulmonary disease (COPD) [1-5]. Analysis of bacterial isolates from patients with COPD, by major outer membrane protein (MOMP) subtyping [6] and deoxyribonucleic acid (DNA) fingerprinting after restriction endonuclease digestion [7], revealed that some $H$. influenzae strains persisted for many months (referred to as persisting strains), whereas other strains were isolated only once (referred to as nonpersisting strains) [5]. The basis for this difference between strains is unknown, but is likely to entail both bacterial and host factors.

The interplay between $H$. influenzae and the airway mucosa in inflammatory airways disease is complex and involves several cell types. Bacterial staining of sections of airways from patients infected with $H$. influenzae showed accumulation of bacteria between and underneath epithelial cells $[8,9]$. In addition, in vitro studies indicated that $H$. influenzae adheres to epithelial cells via specific interactions $[10,11]$. These findings have suggested a role for airway epithelial cells in the pathophysiology of $H$. influenzae colonization. Airway epithelial cells, both in vitro [12-14] and in vivo $[15,16]$, respond to adequate stimulation by the expression of inflammatory mediators, such as interleukin (IL)-6 and IL-8. In fact, it was shown recently that $H$. influenzae-derived lipopolysaccharide, at high concentrations, stimulated airway epithelial cells to release IL-6 and IL-8 [14]. IL-6 is a pleiotropic mediator implicated, among others, in immunoglobulin synthesis [17], and IL-8 mediates the recruitment of neutrophilic granulocytes [18-20]. Both immunoglobulins and neutrophilic granulocytes contribute to the killing of $H$. influenzae [21].

We hypothesized that persisting and nonpersisting $H$. influenzae strains differ in their ability to excert an effect on their local environment. In this hypothesis, we expected persisting strains to be less offensive than nonpersisting strains. Persisting and nonpersisting $H$. 
influenzae strains isolated from chronic bronchitis patients were compared for the induction of IL- 6 and IL-8 production by a human lung epithelial cell line. H292 cells were chosen as they originate from a continuous cell line derived from a pulmonary mucoepidermoid carcinoma. H292 cells show characteristics of differentiation as they express $m u c-2$, indicative of its mucoid character [22], and tight junctions and desmosomes [23], which suggest a polarized phenotype. Furthermore, $H$. influenzae adheres to $\mathrm{H} 292$ cells and subsequently transmigrates across $\mathrm{H} 292$ monolayers [23].

We also assessed whether any difference in the induction of IL- 6 and IL- 8 could be related to adherence of $H$. influenzae to $\mathrm{H} 292$ cells [23], to cytotoxic properties displayed by $H$. influenzae [11], and to the release of a stimulus. In addition, the induction of IL- 6 and IL-8 by $H$. influenzae isolated from patients having signs of lower respiratory tract infection and strains isolated from the throat of healthy carriers was compared.

\section{Materials and methods}

\section{Epithelial cell culture}

H292 cells (American Type Culture Collection CRL 1848, Rockville, MA, USA), were maintained in RPMI1640 medium (Gibco BRL, Paisley, UK) with $0.5 \mathrm{mM}$ glutamic acid (Merck, Darmstadt, Germany) and 10\% heat-inactivated foetal calf serum (Gibco BRL), at $37^{\circ} \mathrm{C}$ in a humidified atmosphere of air with $5 \% \mathrm{CO}_{2}$. For experiments, confluent $\mathrm{H} 292$ cells were exposed in $2 \mathrm{~mL}$ of culture medium in 12-well plates (Costar, Badhoevedorp, The Netherlands).

\section{Bacteria}

Nonencapsulated $H$. influenzae $(\mathrm{n}=15)$ were isolated from sputum samples of patients with chronic bronchitis and characterized as described previously [5-7]. $H$. influenzae strains were considered persisting $(n=9)$ when they were cultured for at least 6 months from various sputum samples from a patient. Nonpersisting $H$. influenzae strains $(n=6)$ were cultured only on one occasion during a monthly follow-up for at least 6 months. Nonencapsulated carrier strains $(n=9)$ were obtained from throat swabs of healthy individuals. All clinical isolates were used within two passages of the original isolation.

\section{Incubation of epithelial cells with $\mathrm{H}$. influenzae}

Bacteria were grown overnight on chocolate agar plates at $37^{\circ} \mathrm{C}$ in a $\mathrm{CO}_{2}$ incubator and were subsequently suspended in complete culture medium to a concentration of $10^{9}$ colony forming units $(\mathrm{cfu}) \cdot \mathrm{mL}^{-1}$ as determined from the optical density of the suspension at $530 \mathrm{~nm}$, and colony counting of serial dilutions as a reference. $\mathrm{H} 292$ cells were exposed to either $10^{6}, 10^{7}, 10^{8}$ or $10^{9}$ $\mathrm{cfu} \cdot \mathrm{mL}^{-1}$, in culture medium supplemented with $25 \mathrm{mM}$ Hepes. At various time intervals culture medium was collected and stored at $-20^{\circ} \mathrm{C}$ until determination of IL-6 and IL-8. Chloramphenicol (CAM) was added to the medium at $3 \mu \mathrm{g} \cdot \mathrm{mL}^{-1}$. This concentration was bacteriostatic since bacterial growth was inhibited without killing them over a period of $24 \mathrm{~h}$, as assessed by cfu countings with serial dilutions of bacterial suspensions. Interleukin-1 $\beta$ (IL-1 $\beta$ ) (Genzyme, Cambridge, MA, USA) was used at $100 \mathrm{U} \cdot \mathrm{mL}^{-1}$ to study the effect of CAM on IL- 6 and IL- 8 production by the cells. To assess epithelial cell damage after 20 and $40 \mathrm{~h}$ of exposure to bacteria, the release of cytoplasmic lactate dehydrogenase (LDH) was measured as described previously [24]. The release of $\mathrm{LDH}$ is expressed as a percentage (mean \pm SEM of triplicate experiments) of total $\mathrm{LDH}$ as determined after cell lysis with $0.1 \%$ (v/v) Triton X-100 (Merck). In some experiments, formation of formazan from the tetrazolium salt 3-(4, 5 dimethylthiazol-2-yl)-2, 5-diphenyltetrazolium bromide (MTT) (Sigma, St. Louis, MO, USA) was quantified as a measure of cell viability and cell proliferation [25]. The formazan levels were expressed as percentage of formazan formation by cells not exposed to bacteria (mean \pm SEM of triplicate experiments). To study the capacity of $H$. influenzae to inhibit IL-6 production by H292 cells, H292 cells were exposed for 24 $\mathrm{h}$ to bacteria, then washed three times with phosphatebuffered saline (PBS) to remove bacteria, incubated again for $4 \mathrm{~h}$ with culture medium without exogenous stimulus, and subsequently exposed to IL-1 $\beta\left(100 \mathrm{U} \cdot \mathrm{mL}^{-1}\right)$ in fresh medium. Culture medium was collected $15 \mathrm{~h}$ later to determine IL-6.

\section{Bacterial adherence to H292 cells}

Adherence of $H$. influenzae to $\mathrm{H} 292$ cells was determined as described [23]. Bacteria were considered adherent when at least 50 bacteria.cell ${ }^{-1}$ could be counted. Bacteria were considered nonadherent and intermediate when less than 5 bacteria or $5-50{\text { bacteria } \cdot \text { cell }^{-1} \text { could }}^{-1}$ be counted, respectively. The influence of CAM present in the cell culture medium on adherence was studied by comparing the adherence of the CAM-sensitive, adhering (nonpersisting) isolate A950009 with the adherence of the adhering but CAM-insensitive laboratory strain QC 2174 (maximal inhibitory concentration (MIC): $8 \mu \mathrm{g} \cdot \mathrm{mL}^{-1}$ ).

\section{Characterization of the bacterial stimulus}

Bacteria were grown in brain heart infusion broth (BHI) supplemented with hemin and nicotinamide adenine dinucleotide (10 $\mathrm{mg} \cdot \mathrm{L}^{-1}$ each), with shaking (120 revolutions per minute (rpm)) at $37^{\circ} \mathrm{C}$ in a humidified atmosphere of air with $5 \% \mathrm{CO}_{2}$. Samples were taken at $6 \mathrm{~h}$, after which the medium was separated from bacteria by centrifugation at $5,000 \times \mathrm{g}$ for $15 \mathrm{~min}$, and subsequently filtered through a filter with a $0.2 \mu \mathrm{m}$ pore size (Schleicher and Schuell, Dassel, Germany). The culture filtrate was dialysed overnight against PBS. To denature protein, the filtrate was boiled for $5 \mathrm{~min}$ or exposed to $5 \%$ trichloroacetic acid (TCA; Merck) for 5 min at $0^{\circ} \mathrm{C}$ followed by centrifugation. The resulting acid supernatant was dialysed overnight against PBS before further analysis. Lipopolysaccharide was removed 
by binding to polymyxin $\mathrm{B}$ immobilized to agarose (Boehringer Mannheim, Mannheim, Germany) for $18 \mathrm{~h}$ at room temperature followed by centrifugation to pellet the agarose beads. Lipids were removed by extraction with a mixture of chloroform and diethylether (1:1), followed by centrifugation to separate the aqueous phase from the lipid phase. Subsequently, the aqueous phase was exposed to a flow of nitrogen to remove traces of ether and chloroform.

\section{Determination of pro-inflammatory mediators}

IL- 6 and IL-8 were determined by enzyme-linked immunosorbent assay (ELISA), essentially according to Helle et al. [26] and to HACK et al. [27], respectively.

\section{Statistical analysis}

The induction of IL- 6 and IL- 8 production by each strain was determined in three to six independent experiments performed in duplicate. The IL-6 and IL-8 levels were expressed as the mean \pm SEM. The nonparametric Mann-Whitney U-test (MWU-test) and the Wilcoxon signed-ranks test (WSR-test) were used for comparison between different groups and different experimental conditions, as indicated in the text. The three groups of isolates were compared using the Kruskall-Wallis test. Bonferroni's correction for the risk of mass significance with multiple comparisons between the three groups was performed.

Analysis of variance (ANOVA) [28] was used to account for experimental differences between days in the induction of IL-6 and IL-8 production by persisting, nonpersisting and throat isolates. The day and the type of strain were used as fixed factors, and the individual strain as random factor. The IL-6 and IL-8 data were logarithmically transformed before analysis. Restricted maximum likelihood was used to fit the data. The p-values were calculated from the Wald test. In pairwise comparisons between types, a p-value adjusted for multiple comparisons was calculated according to the Hommel procedure [29]. Residual analyses were performed to check some assumptions (normality of between and within strain residuals and constancy of between and within SD) as well as to identify outliers. The statistical packages BMDP386 and BMDP-PC90 (BMDP Statistical Software, Inc., Los Angeles, CA, USA) were used for the calculations.

The Spearman rank correlation test was used to assess the correlation between the induction of IL- 6 and IL- 8 by H. influenzae.

A p-value of less than 0.05 was considered significant.

\section{Results}

Effect of chloramphenicol on IL-6 and IL-8 production in H292 cells

In the absence of bacteria, H292 cells spontaneously released $23 \pm 3 \mathrm{pg} \cdot \mathrm{mL}^{-1}$ of IL-6 $(\mathrm{n}=6$; duplicate experiments) and $161 \pm 22 \mathrm{pg} \cdot \mathrm{mL}^{-1}$ of IL-8 $(\mathrm{n}=3$; duplicate experiments) over $24 \mathrm{~h}$. To be able to determine the dose-dependent induction of IL- 6 and IL- 8 by bacterial strains, the H292 culture medium was supplemented with $3 \mu \mathrm{g} \cdot \mathrm{mL}^{-1}$ chloramphenicol (CAM). In the absence and presence of CAM, H292 cells stimulated for $7 \mathrm{~h}$ with IL-1 $\beta(\mathrm{n}=6)$ released $394 \pm 26 \mathrm{pg} \cdot \mathrm{mL}^{-1}$ and $396 \pm 35$ $\mathrm{pg} \cdot \mathrm{mL}^{-1}$ of IL-6, respectively, and $1609 \pm 165 \mathrm{pg} \cdot \mathrm{mL}^{-1}$

Table 1. - Interleukin (IL)-6 and IL-8 production by $\mathrm{H} 292$ cells induced by $10^{7}$ colony forming units (cfu) $\mathrm{mL}^{-1}$ of various Haemophilus influenzae isolates in the absence or presence of chloramphenicol (CAM) in the culture medium

\begin{tabular}{lcc}
\hline & $\begin{array}{c}\text { IL-6 } \\
\mathrm{pg} \cdot \mathrm{mL}^{-1}\end{array}$ & $\begin{array}{c}\mathrm{IL}-8 \\
\mathrm{pg} \cdot \mathrm{mL}^{-1}\end{array}$ \\
\hline Without CAM & $100(30-1000)$ & $2015(860-7615)$ \\
With CAM & $200(40-450)$ & $1758(710-2640)$ \\
\hline
\end{tabular}

Values are presented as median, and range in parenthesis. All experiments were performed in duplicate. For IL-6 there were 12 isolates (four persisting, four nonpersisting and four throat isolates) (Wilcoxon Sign Rank (WSR)-test: $\mathrm{p}=0.25$ ). For IL8 there were four throat isolates (WSR-test: $\mathrm{p}=0.64$ ).
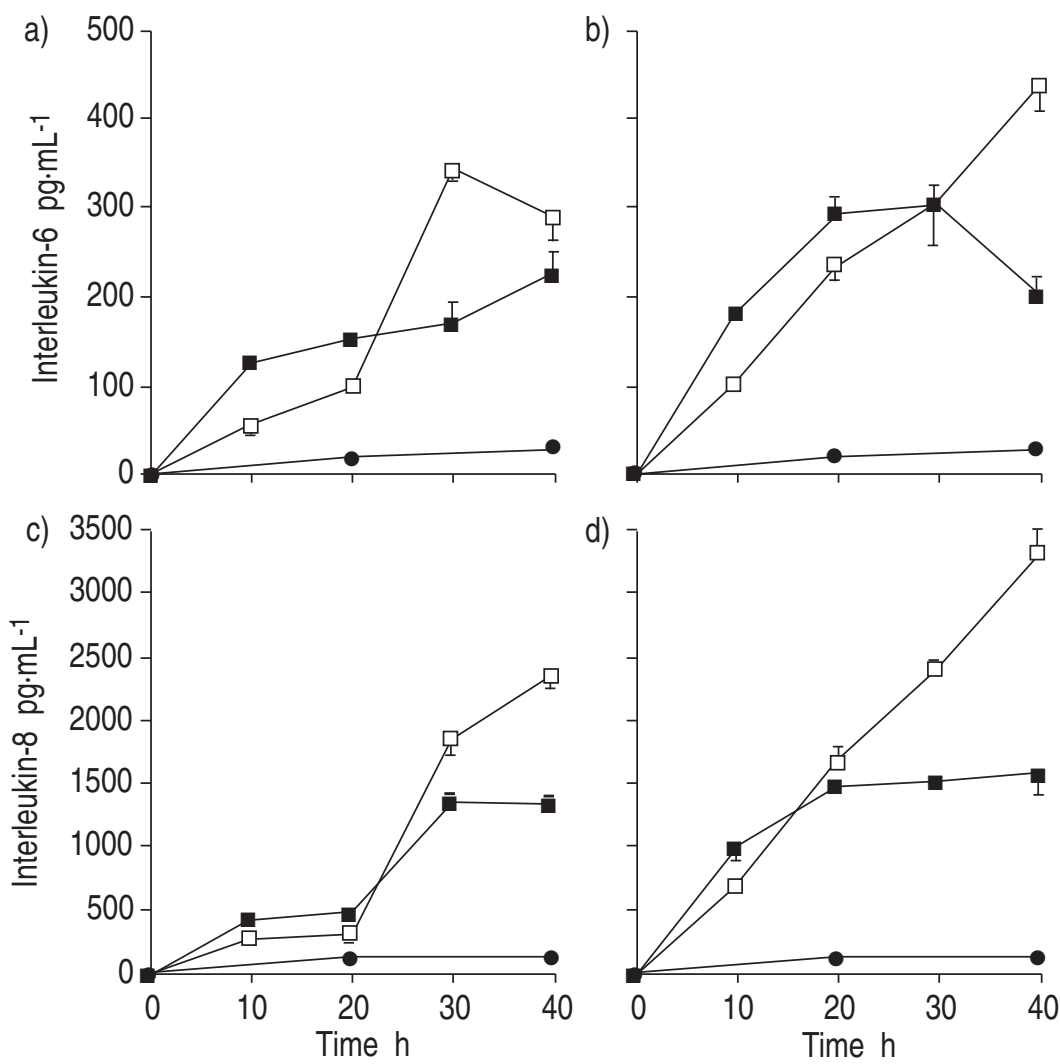

Fig. 1. - Time-dependent production of interleukin (IL)-6 by H292 cells exposed to Haemophilus influenzae: a) persisting isolate A950004; and b) nonpersisting isolate A950005; and production of IL- 8 by: c) isolate A950004; and d) isolate A950005. Confluent H292 cells were exposed to $10^{7}$ colony forming units $(\mathrm{cfu}) \cdot \mathrm{mL}^{-1}(\square), 10^{8} \mathrm{cfu} \cdot \mathrm{mL}^{-1}(\mathbf{\square})$ or no bacteria $(\bullet)$. Each point represents the mean \pm SD of triplicate experiments. 
and $1703 \pm 160 \mathrm{pg} \cdot \mathrm{mL}^{-1}$ of IL-8, respectively. Furthermore, the amounts of IL- 6 and IL-8 produced after $24 \mathrm{~h}$ exposure of $\mathrm{H} 292$ cells to $10^{7} \mathrm{cfu} \cdot \mathrm{mL}^{-1}$ in the presence of CAM were similar to those in the absence of CAM (table 1).

\section{Dose-dependent induction of $I L-6$ and $I L-8$}

H292 cells were exposed to $10^{6}, 10^{7}, 10^{8}$ or $10^{9}$ cfu $\cdot \mathrm{mL}^{-1}$ of 12 different $H$. influenzae strains for $24 \mathrm{~h}$ in the presence of CAM. Exposure of H292 cells to $10^{6}$ $\mathrm{cfu} \cdot \mathrm{mL}^{-1}$ did not, or only to a small extent, result in the production of IL- 6 and IL-8. Exposure of cells to $10^{9}$ $\mathrm{cfu} \cdot \mathrm{mL}^{-1}$ resulted in the production of $100 \mathrm{pg} \cdot \mathrm{mL}^{-1}$ of IL-6 at the most. However, in the presence of $10^{9}$ $\mathrm{cfu} \cdot \mathrm{mL}^{-1}$ the culture medium acidified rapidly and the epithelial cells detached from the culture plates within $24 \mathrm{~h}$. After exposure to $10^{7}$ and $10^{8} \mathrm{cfu} \cdot \mathrm{mL}^{-1}$ of $\mathrm{H}$. in fluenzae, both IL-6 and IL-8 were produced and increased during at least $20 \mathrm{~h}$. Figure 1 shows time courses of IL-6 and IL-8 production by H292 cells upon exposure to $10^{7}$ and $10^{8} \mathrm{cfu} \cdot \mathrm{mL}^{-1}$ of strains A950004 (persisting) and A950005 (nonpersisting), which are representative of the 12 isolates tested. It is of interest to note that levels of IL-6 and IL- 8 induced by $10^{8} \mathrm{cfu} \cdot \mathrm{mL}^{-1}$ of both strains during the first $20 \mathrm{~h}$ of exposure are usually higher than those induced by $10^{7} \mathrm{cfu} \cdot \mathrm{mL}^{-1}$. Epithelial cells exposed to $10^{7}$ or $10^{8} \mathrm{cfu} \cdot \mathrm{mL}^{-1}$ during $20 \mathrm{~h}$ remained, like unexposed cells, apparently normal as assessed by light microscopy, and the $\mathrm{pH}$ of the culture medium remained between 7 and 8 . After $40 \mathrm{~h}$ of exposure to $10^{8} \mathrm{cfu} \cdot \mathrm{mL}^{-1}$, but not with $10^{7} \mathrm{cfu} \cdot \mathrm{mL}^{-1}$, the culture medium acidified. In further experiments, IL-6 and IL-8 were determined in samples taken after 20-24 h of exposure to $10^{7}$ or $10^{8} \mathrm{cfu} \cdot \mathrm{mL}^{-1}$.

Comparison of IL-6 and IL-8 levels induced by persisting and nonpersisting $\mathrm{H}$. influenzae

The induction of IL- 6 and IL- 8 by the various bronchitis isolates, i.e. nine persisting and six nonpersisting strains, was compared with nine throat isolates from healthy individuals. The data for IL-6 production are depicted in figure 2. Some strains evoked maximal IL-6 production at $10^{7} \mathrm{cfu} \cdot \mathrm{mL}^{-1}$, others at $10^{8} \mathrm{cfu} \cdot \mathrm{mL}^{-1}$ and some induced similar levels at $10^{7}$ and $10^{8} \mathrm{cfu} \cdot \mathrm{mL}^{-1}$, irrespective of whether persisting, nonpersisting or throat isolates were exposed to the H292 cells. Statistical analysis of the IL-6 levels induced by exposure to $H$. influenzae showed that persisting strains were relatively weak inducers of IL-6 production compared to nonpersisting strains, both evaluated for $10^{7} \mathrm{cfu} \cdot \mathrm{mL}^{-1}$ (MWU-test: $\mathrm{p}<0.05$ ) and for the number of $\mathrm{cfu} \cdot \mathrm{mL}^{-1}$ causing maximal production of IL- $6(\mathrm{p}<0.05)$. The levels of IL-6 induced by throat isolates at $10^{7} \mathrm{cfu} \cdot \mathrm{mL}^{-1}$ and the maximal production did not differ significantly from those induced by persisting and nonpersisting isolates from bronchitis patients, although they tended to be higher than persisting isolates.

The data for IL-8 production are depicted in figure 3 . The levels of IL-8 induced by $10^{8} \mathrm{cfu} \cdot \mathrm{mL}^{-1}$ of all strains (median 2059

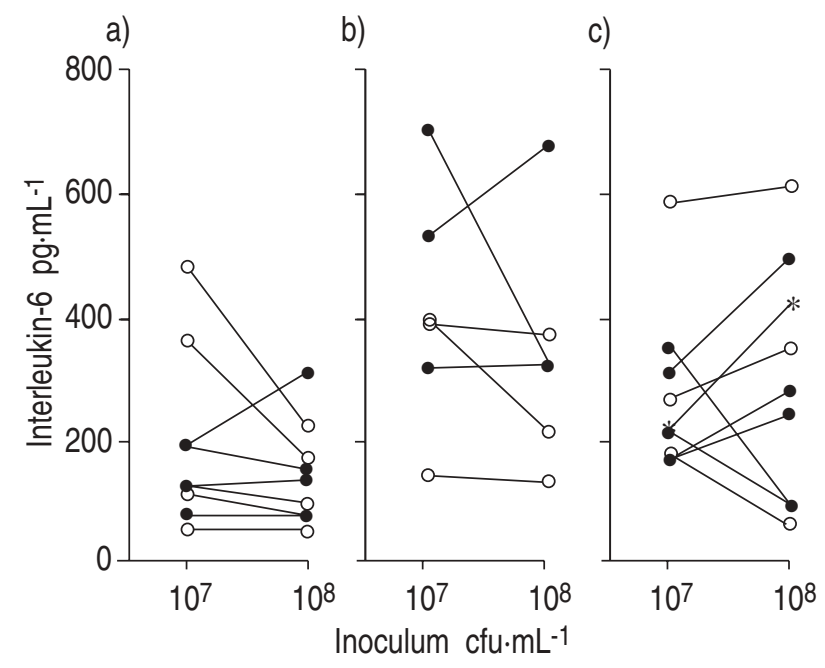

Fig. 2. - Production of interleukin (IL)-6 after $24 \mathrm{~h}$ of exposure to Haemophilus influenzae as a function of inoculum: a) nine persisting strains; b) six nonpersisting strains; and c) nine throat isolates. Means obtained for individual strains of 3-6 separate experiments in duplicate are shown. •: adhering bacteria; ○: nonadhering bacteria; *: adherence not determined. cfu: colony forming units

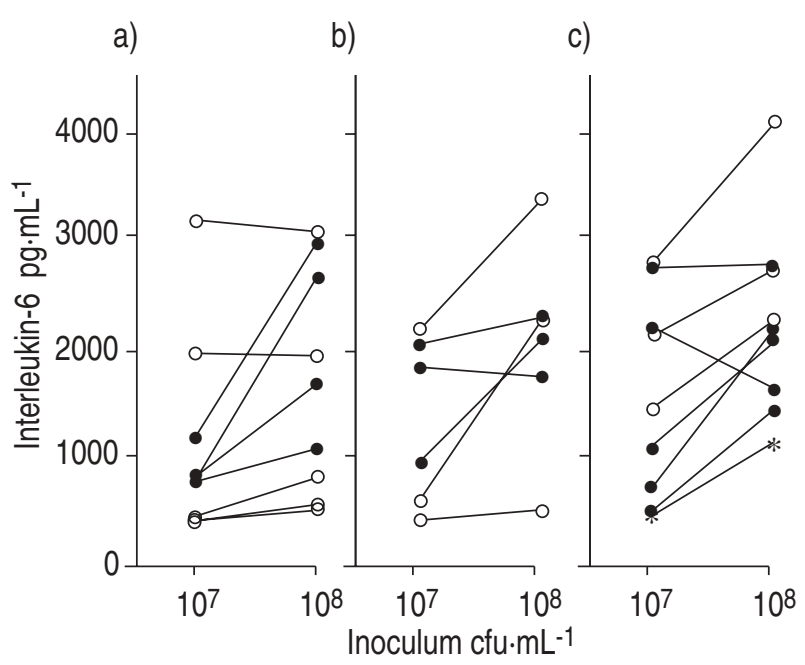

Fig. 3. - Production of interleukin (IL)-8 after $24 \mathrm{~h}$ of exposure to Haemophilus influenzae as a function of inoculum: a) nine persisting strains; b) six nonpersisting strains; and c) nine throat isolates. Means obtained for individual strains of 3-6 separate experiments in duplicate are shown. $\bullet$ : adhering bacteria; o: nonadhering bacteria; *: adherence not determined.

Table 2. - Maximal interleukin 6 (IL-6) production by $\mathrm{H} 292$ cells in the presence of $10^{7}$ or $10^{8}$ colony forming units (cfu) $\cdot \mathrm{mL}^{-1}$ of nine persisting, six nonpersisting and nine throat isolates of Haemophilus influenzae, adjusted for differences between days with analysis of variance after logarithmic transformation of the data

\begin{tabular}{|c|c|c|c|c|c|}
\hline \multirow[t]{2}{*}{ H. influenzae } & \multirow[b]{2}{*}{$\begin{array}{c}\text { IL-6 } \\
\text { production* }\end{array}$} & \multicolumn{2}{|c|}{$\begin{array}{l}\text { SEM of difference } \\
\text { with strain }\end{array}$} & \multicolumn{2}{|c|}{ p-value ${ }^{+}$} \\
\hline & & $\begin{array}{c}\text { Non- } \\
\text { persisting }\end{array}$ & Throat & Unadjusted & $\begin{array}{l}\text { Hommel } \\
\text { adjusted }\end{array}$ \\
\hline Persi & $4.89 \pm 0.19$ & 0.32 & 0.27 & - & - \\
\hline Nonpersisting & $5.65 \pm 0.26$ & & 0.33 & 0.017 & 0.017 \\
\hline Throat & $5.73 \pm 0.19$ & & & 0.0015 & 0.0030 \\
\hline
\end{tabular}

*: values presented as the mean \pm SEM of the natural logarithm of the values in $\mathrm{pg} \cdot \mathrm{mL}^{-1} ;{ }^{+}$: comparison with persisting strain. 
$\mathrm{pg} \cdot \mathrm{mL}^{-1}$, range $495-4,049 \mathrm{pg} \cdot \mathrm{mL}^{-1}$ ) were significantly higher compared to those induced by $10^{7} \mathrm{cfu} \cdot \mathrm{mL}^{-1}$ of all strains (median 1,011, range: $404-3,145 \mathrm{pg} \cdot \mathrm{mL}^{-1}$ ) (WSR-test: $\mathrm{p}<0.001)$. Analysis of the IL-8 levels induced by the three groups of isolates revealed only a slight tendency for persisting strains to induce lower levels than nonpersisting strains without reaching statistical significance.

The differences in the maximal induction of IL- 6 between the three groups of strains was analysed by ANOVA and were found to be highly significant (table $2, \mathrm{p}<0.005$ ). Both throat isolates and nonpersisting bronchitis isolates induced significantly higher levels of IL-6
compared to the persisting bronchitis isolates. Essentially the same results were obtained in the analysis of persisting, nonpersisting and throat isolates for the induction of IL-6 with $10^{7} \mathrm{cfu} \cdot \mathrm{mL}^{-1}$. A similar analysis was also carried out for IL-8 (table 3 ). The maximal IL-8 production differed significantly between the three groups $(\mathrm{p}<0.02)$. After Hommel adjustment, the differences between nonpersisting and persisting bronchitis isolates and between throat isolates and persisting isolates were both statistically significant (table 3 ). The suboptimal levels of IL- 8 induced by $10^{7} \mathrm{cfu} \cdot \mathrm{mL}^{-1}$ were similar for the three groups, but tended to be higher for nonpersisting than persisting isolates (Hommel adjusted: $\mathrm{p}=0.13$ ).

The mean levels of IL- 6 and IL- 8 induced by $10^{7}$ $\mathrm{cfu} \cdot \mathrm{mL}^{-1}$ of all 24 isolates, irrespective of their source or persistency, were significantly correlated (Spearman rho $0.62, \mathrm{p}<0.002$; data not shown). In contrast, no significant correlation was present if cells were exposed to $10^{8}$ $\mathrm{cfu} \cdot \mathrm{mL}^{-1}$ of these isolates (rho $0.38, \mathrm{p}=0.07$; data not shown).

\section{Effect of bacteria on viability and proliferation of $\mathrm{H} 292$ cells}

H292 cells were incubated for 20 and $40 \mathrm{~h}$ with $10^{7}$ and $10^{8} \mathrm{cfu} \cdot \mathrm{mL}^{-1}$ of five $H$. influenzae strains, inducing different levels of IL- 6 and IL-8. Table 4 summarizes the characteristics of two persisting, two nonpersisting and one throat isolate, with respect to the induction of IL-6 and IL-8. At $20 \mathrm{~h}$, both for $10^{7}$ and $10^{8} \mathrm{cfu} \cdot \mathrm{mL}^{-1}$, the $\mathrm{LDH}$ release induced by either strain was less than $4 \%$ of total LDH. After $40 \mathrm{~h}$ of incubation with $10^{7} \mathrm{cfu} \cdot \mathrm{mL}^{-1}$, all strains induced $4.5 \pm 4.2 \% \mathrm{LDH}$ release and for $10^{8}$ $\mathrm{cfu} \cdot \mathrm{mL}^{-1}$ the release was $7.6 \pm 3.6 \%$. At 20 $\mathrm{h}$, formazan formation was $61.2 \pm 3.4 \%$ for $10^{7} \mathrm{cfu} \cdot \mathrm{mL}^{-1}$ and $50.3 \pm 4.6 \%$ for $10^{8}$ $\mathrm{cfu} \cdot \mathrm{mL}^{-1}$ (WSR- test: $\mathrm{p}=0.06$ ) of control values. At $40 \mathrm{~h}$, formazan formation was $79.2 \pm 11.5 \%$ and $52.0 \pm 6.8 \%$ for $10^{7}$ and $10^{8}$ cfu. $\mathrm{mL}^{-1}$, respectively, (WSR-test: $\mathrm{p}=0.13$ ). The presence of CAM did not influence the formazan formation in $\mathrm{H} 292$ cells not exposed to bacteria. Differences between strains in LDH release and formazan formation were not observed, whilst induction of IL-6 and IL-8 differed between the strains (table 4 ).
Table 4. - Interleukin (IL)- 6 and IL-8 production after $20 \mathrm{~h}$ and $40 \mathrm{~h}$ of exposure to Haemophilus influenzae

\begin{tabular}{lcccccc}
\hline Strain & $\begin{array}{c}\text { Inoculum } \\
\text { cfu·mL-1 }\end{array}$ & \multicolumn{2}{c}{$\mathrm{IL}-6 \mathrm{pg} \cdot \mathrm{mL}^{-1}$} & & \multicolumn{2}{c}{$\mathrm{IL}-8 \mathrm{pg} \cdot \mathrm{mL}^{-1}$} \\
\cline { 3 - 4 } \cline { 6 - 7 } & & $20 \mathrm{~h}$ & $40 \mathrm{~h}$ & & $20 \mathrm{~h}$ & $40 \mathrm{~h}$ \\
\hline A950003* $^{*}$ & $10^{7}$ & $161 \pm 25$ & $1583 \pm 62$ & & $474 \pm 32$ & $1743 \pm 89$ \\
& $10^{8}$ & $418 \pm 22$ & $493 \pm 25$ & & $750 \pm 121$ & $1852 \pm 134$ \\
A950004* $^{*}$ & $10^{7}$ & $100 \pm 8$ & $288 \pm 33$ & & $335 \pm 16$ & $2335 \pm 88$ \\
& $10^{8}$ & $154 \pm 8$ & $226 \pm 24$ & & $480 \pm 13$ & $1349 \pm 56$ \\
A950005 $^{+}$ & $10^{7}$ & $236 \pm 19$ & $437 \pm 27$ & & $1659 \pm 112$ & $3302 \pm 174$ \\
& $10^{8}$ & $294 \pm 17$ & $200 \pm 22$ & & $1480 \pm 69$ & $1575 \pm 155$ \\
A950006 $^{+}$ & $10^{7}$ & $339 \pm 13$ & $753 \pm 11$ & & $2008 \pm 48$ & $3187 \pm 88$ \\
& $10^{8}$ & $429 \pm 13$ & $393 \pm 14$ & & $1547 \pm 133$ & $1835 \pm 78$ \\
A930065 $^{\dagger}$ & $10^{7}$ & $279 \pm 11$ & $1175 \pm 68$ & & $911 \pm 36$ & $996 \pm 52$ \\
& $10^{8}$ & $540 \pm 15$ & $489 \pm 46$ & & $1307 \pm 170$ & $1620 \pm 112$
\end{tabular}

Data are presented as mean \pm SEM values from six independent experiments. *: persisting strain; ${ }^{+}$: nonpersisting strain; ${ }^{\dagger}$ : throat strain. 
Table 5. - Effect of bacterial pre-exposure of H292 cells on interleukin (IL)-1 $\beta$-induced IL-6 production

\begin{tabular}{lccc}
\hline \multirow{2}{*}{ Strain } & $\begin{array}{c}\text { Inoculum } \\
\text { cfu·mL-1 }\end{array}$ & $\begin{array}{c}\text { IL-6 production } \\
\text { pg.mL-1 }\end{array}$ & $\begin{array}{c}\text { After IL-1 } \\
\mathrm{pg} \cdot \mathrm{mL}^{-1}\end{array}$ \\
\hline A950004* & $10^{7}$ & $198 \pm 13$ & 1640,1520 \\
& $10^{8}$ & $157 \pm 42$ & 2580,1650 \\
A950005+ & $10^{7}$ & $351 \pm 33$ & 1530,1780 \\
No bacteria & $10^{8}$ & $628 \pm 190$ & 2980,2420 \\
\hline
\end{tabular}

\#: IL-6 production after $24 \mathrm{~h}$ exposure to bacteria, mean \pm SD of quadruplicate experiments; $¥$ : IL-6 production after $15 \mathrm{~h}$ exposure to IL-1 $\beta$ (100 U.mL $\left.\mathrm{m}^{-1}\right)$, duplicate experiments; *: persisting strain; +* nonpersisting strain.

Persisting $\mathrm{H}$. influenzae isolates did not affect the capacity of H292 cells to produce IL-6

$\mathrm{H} 292$ cells were incubated for $24 \mathrm{~h}$ to $10^{7}$ and $10^{8}$ $\mathrm{cfu} \cdot \mathrm{mL}^{-1}$ with either a persisting (A950004) or nonpersisting strain (A950005), after which IL-1 $\beta$ was added to the cell culture medium. The results, summarized in table 5, show that IL-6 production by $\mathrm{H} 292$ cells was not hampered after pre-exposure to bacteria for $24 \mathrm{~h}$, and that there was no difference between persisting and nonpersisting $H$. influenzae.

Initial characterization of bacterial component(s) that induced cytokine production by $\mathrm{H} 292$ cells

H292 cells were exposed for $20 \mathrm{~h}$ to the culture filtrates of the persisting strain A950004 and the nonpersisting strain A950005. Exposure of H292 cells for 20 $\mathrm{h}$ to the culture filtrate (1:10 diluted) of the persisting strain A950004 and the nonpersisting strain A950005 induced the production of $124 \pm 16 \mathrm{pg} \cdot \mathrm{mL}^{-1}(\mathrm{n}=4$, duplicate experiments), and $314 \pm 70 \mathrm{pg} \cdot \mathrm{mL}^{-1}(\mathrm{n}=4$, duplicate experiments), respectively, compared to the release of $23 \pm 3$

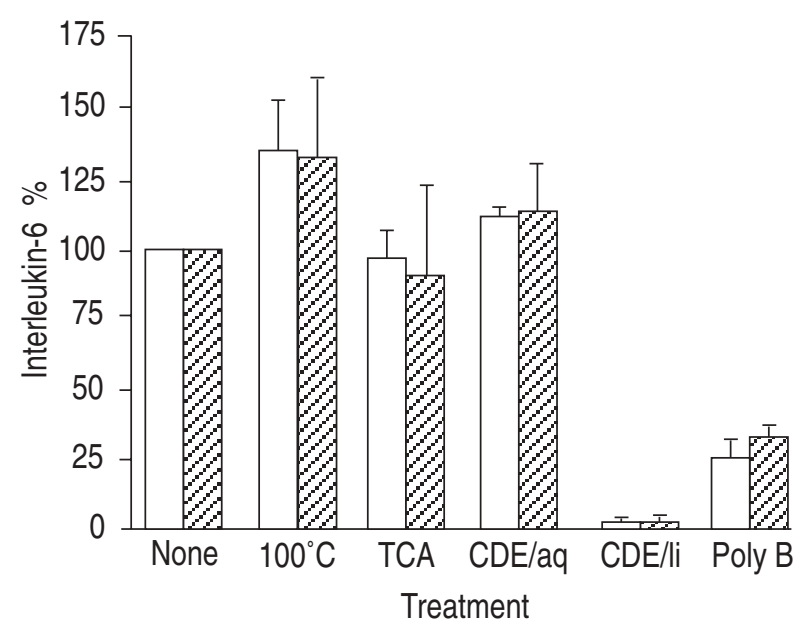

Fig. 4. - Production of interleukin (IL)-6 after $20 \mathrm{~h}$ of exposure to Haemophilus influenzae culture filtrates. Bacterial products released in brain heart infusion broth (BHI) were treated by boiling $\left(100^{\circ} \mathrm{C}\right)$, $5 \%$ trichloroacetic acid (TCA), chloroformdiethylether (CDE) or polymyxin B (poly B), as described in Materials and methods. CDE/aq: aqueous phase; CDE/li: lipid phase. Values are mean \pm SEM of two independent duplicate experiments, expressed as the percentage of the IL- 6 levels induced by untreated culture filtrates. Background IL6 inductions was subtracted. $\square$ : A950004; $\square$ : A950005. $\mathrm{pg} \cdot \mathrm{mL}^{-1}$ in the control experiments $(\mathrm{n}=6$, duplicate experiments). The stimulating component(s) were not extracted with chloroform-ether, indicating that they were not associated with the lipid fraction. Boiling and TCAprecipitation also had no effect on the activity of the culture filtrate, practically ruling out a protein being responsible for the cytokine induction. However, the activity was partially reduced by incubation with immobilized polymyxin B (fig. 4).

\section{Discussion}

In the present study, we assessed whether persisting and nonpersisting $H$. influenzae isolates from patients with chronic bronchitis differ, particularly in the induction of IL-6 and IL-8 production by epithelial cells. All isolates induced IL-6 and IL8 production in a time and dose-dependent fashion. Both a straightforward statistical analysis and a more extensive analysis showed that persisting isolates induced lower levels of IL-6 than nonpersisting isolates. For the IL- 8 induction by persisting isolates in comparison to nonpersisting isolates there was a similar tendency, but not as clear cut as for IL-6. Levels of IL-6 and IL-8 induced by throat isolates from healthy carriers overlapped with those from chronic bronchitis isolates (figs. 2 and 3).

To be able to compare the various $H$. influenzae isolates for their ability to induce IL-6 and IL-8 production by $\mathrm{H} 292$ cells, we had to control the bacterial load during exposure to the $\mathrm{H} 292$ cells [14]. By using CAM at $3 \mu \mathrm{g} \cdot \mathrm{mL}^{-1}$ we prevented bacterial replication without killing the bacteria. In addition, IL- $1 \beta$-induced IL- 6 and IL- 8 production by $\mathrm{H} 292$ cells was similar in the absence and presence of CAM, suggesting that IL-6 and IL-8 production by $\mathrm{H} 292$ cells was not modulated in the presence of CAM. Also, exposure of H292 cells to $10^{7} \mathrm{cfu} \cdot \mathrm{mL}^{-1}$ of $H$. influenzae in the absence or presence of CAM yielded similar amounts of IL- 6 and of IL-8, indicating that, in general, the induction of IL-6 and IL- 8 by $H$. influenzae was not affected by the presence of CAM, at least during a $24 \mathrm{~h}$ exposure. CAM did not directly affect the adherence of $H$. influenzae to H292 cells. The observed reduction in adherence with CAM-sensitive strains is probably the consequence of reduced growth of bacteria on the cells, since the adherence experiments involve a $6 \mathrm{~h}$ incubation [23]. Taken together, we have no indications that inclusion of CAM would bias comparison of the various isolates.

Using $10^{6}$ to $10^{9} \mathrm{cfu} \cdot \mathrm{mL}^{-1}$ of $H$. influenzae strains we found a pronounced IL- 6 and IL-8 production only with $10^{7}$ and $10^{8} \mathrm{cfu} \cdot \mathrm{mL}^{-1}$. IL-6 and IL-8 levels increased during at least 20-24 h of exposure. Between 20-40 h of bacterial exposure to $\mathrm{H} 292$ cells, particularly with $10^{8} \mathrm{cfu} \cdot \mathrm{mL}^{-1}$, IL-6 and IL-8 levels were similar or reduced in comparison to those obtained after the initial $20 \mathrm{~h}$ of exposure (fig. 1, table 4). With $10^{7} \mathrm{cfu} \cdot \mathrm{mL}^{-1}$, IL-6 levels usually increased further after $20 \mathrm{~h}$ of exposure. This difference may be explained in part by limited cellular damage induced by $10^{8} \mathrm{cfu} \cdot \mathrm{mL}^{-1}$ as evidenced by the increased release of cellular LDH and a reduced formazan formation after $40 \mathrm{~h}$ of exposure to $10^{8}$ $\mathrm{cfu} \cdot \mathrm{mL}^{-1}$ but not upon exposure to $10^{7} \mathrm{cfu} \cdot \mathrm{mL}^{-1}$. Since there was no cellular damage induced after $20 \mathrm{~h}$ of exposure to bacteria, and levels of IL-6 and IL- 8 had 
not reached plateau levels, we compared the various strains for the induction of IL-6 and IL-8 after 20-24 h of exposure to $H$. influenzae.

The numbers of $\mathrm{cfu} \cdot \mathrm{mL}^{-1}$ we tested occur in clinical sputum samples $\left(4 \times 10^{4}-4 \times 10^{7} \mathrm{cfu} \cdot \mathrm{mL}^{-1} ;[30]\right)$. Since these values of $\mathrm{cfu} \cdot \mathrm{mL}^{-1}$ induced IL-6 and IL-8 production in vitro, this may indicate that $H$. influenzae may induce IL-6 and IL-8 in vivo, thus contributing to the eradication of $H$. influenzae [21]. Nevertheless, extrapolation of the present findings to the interactions of $H$. influenzae with airway epithelial cells in vivo should be performed with caution.

The induction of IL- 6 and IL- 8 by isolates correlated significantly for $10^{7} \mathrm{cfu} \cdot \mathrm{mL}^{-1}$ suggesting that the same stimulus induces IL- 6 and IL- 8 production by $\mathrm{H} 292$ cells. The reason for the more obvious differences between strains for the induction of IL- 6 than for IL- 8 are unknown, but may be due to differences in the regulation of the IL- 8 response by $\mathrm{H} 292$ cells. The initial characterization of the stimulus indicated that it is released by the bacteria and that it is probably not a lipid or protein. A polysaccharide can be excluded since these $H$. influenzae strains are unencapsulated. LPS or LPSbound component(s) [31] are responsible for a major part of the interleukin induction, since approximately $70 \%$ of the activity was removed by polymyxin $\mathrm{B}$. The remaining activity may be caused by a second stimulus, which is also neither a protein nor a lipid. Therefore, we propose that persisting and nonpersisting isolates differ in their ability to induce IL- 6 and IL- 8 because they differ in the excretion of a (complex) stimulus.

Future studies should be directed to further characterization of the bacterial stimulus that induces IL-6 and IL- 8 production by $\mathrm{H} 292$ cells. This would allow quantitative comparison of persisting and nonpersisting isolates and also assessment of IL- 6 and IL- 8 induction by this stimulus in cultured primary airway epithelium.

In conclusion, Haemophilus influenzae isolates that differ clinically, i.e. persisting versus nonpersisting, differ in the induction of interleukin- 6 and interleukin- 8 by $\mathrm{H} 292$ cells. We suggest that persisting isolates generate lower amounts of a stimulus that activates epithelial cells to produce interleukin- 6 and interleukin-8, which may, at least in part, contribute to their persistence. It is likely that $H$. influenzae isolates in the lower respiratory tract originate from the upper airways, especially the nasopharynx, the natural habitat for $H$. influenzae. If anything, our results for throat isolates from healthy carriers may point to the possibility that persisting $H$. influenzae strains are selected from throat strains that induce low levels of interleukin-6 and interleukin-8.

Acknowledgements: The authors thank P. Eijk, S. Loman, I. Peerdeman and E. Geerlings for their practical advice and assistance in some experiments. T.A. Out and J.S. van der Zee are acknowledged for their comments on the manuscript.

\section{References}

1. Turk DC. The pathogenicity of Haemophilus influenzae. J Med Microbiol 1984; 18: 1-16.

2. Murphy TF, Apicella MA. Nontypable Haemophilus influenzae: a review of clinical aspects, surface anti- gens, and the human immune response to infection. Rev Infect Dis 1987; 9: 2-15.

3. Murphy TF, Sethi S. Bacterial infection in chronic obstructive pulmonary disease. Am Rev Respir Dis 1992; 146: $1067-1083$.

4. Groeneveld K, Eijk PP, van Alphen L, Jansen HM, Zanen HC. Haemophilus influenzae infections in patients with chronic obstructive pulmonary disease despite antibodies in serum and sputum. Am Rev Respir Dis 1990; 141: 1316-1321.

5. Groeneveld K, van Alphen L, Eijk PP, Visschers G, Jansen HM, Zanen HC. Endogenous and exogenous reinfections by Haemophilus influenzae in patients with chronic obstructive pulmonary disease; the effect of antibiotic treatment upon persistence. J Infect Dis 1990; 161: 512-517.

6. Van Alphen L, Riemens T, Poolman J, Zanen HC. Characteristics of major outer membrane proteins of Haemophilus influenzae. J Bacteriol 1983; 155: 878-885.

7. Groeneveld K, van Alphen L, Eijk PP, Jansen HM, Zanen HC. Changes in outer membrane proteins of nontypable Haemophilus influenzae in patients with chronic obstructive pulmonary disease. J Infect Dis 1988; 158; 360-365.

8. Hers JFP, Mulder J. The mucosal epithelium of the respiratory tract in muco-purulent bronchitis caused by Haemophilus influenzae. J Path Bact 1953; 56: 103-108.

9. Clarke CW, Hannant CA, Scicchitano R, Donald KJ, Jackson B. Antigen of Haemophilus influenzae in bronchial tissue. Thorax 1981; 36: 665-668.

10. Van Alphen L, van Ham SM. Adherence and invasion of Haemophilus influenzae. Rev Med Microbiol 1994; 5: 245-255.

11. Read RC, Wilson R, Rutman A, et al. Interaction of non-typable Haemophilus influenzae with human respiratory mucosa in vitro. J Infect Dis 1991; 163: 549-558.

12. Massion PP, Inoue H, Richman-Eisenstat J, et al. Novel Pseudomonas product stimulates interleukin- 8 production in airway epithelial cells in vitro. J Clin Invest 1994: 93: 26-32.

13. Bédard M, McClure CD, Schiller NL, Francoeur C, Cantin A, Denis M. Release of interleukin-8, interleukin-6 and colony-stimulating factor by upper airway epithelial cells: implications for cystic fibrosis. Am J Respir Cell Mol Biol 1993; 9: 455-462.

14. Khair OA, Devalia JL, Abdelaziz MM, Sapsford RJ, Tarraf H, Davies RJ. Effect of Haemophilus influenzae endotoxin on the synthesis of IL-6, IL- 8 , TNF- $\alpha$ and the expression of ICAM-1 in cultured human bronchial epithelial cells. Eur Respir J 1994; 7: 2109-2116.

15. Marini M, Vittori E, Hollemborg J, Mattoli S. Expression of the potent inflammatory cytokines, granulocytemacrophage-colony-stimulating factor and interleukin-6 and interleukin-8, in bronchial epithelial cells of patients with asthma. J Allergy Clin Immunol 1992; 89: 1001-1009.

16. Mattoli S, Mattoso VL, Soloperto M, Allegra L, Fasoli A. Cellular and biochemical characteristics of bronchial lavage fluid in symptomatic nonallergic asthma. J Allergy Clin Immunol 1991; 87: 794-802.

17. Hirano T, Yasukawa K, Harada H, et al. Complementary DNA for a novel human interleukin (BSF-2) that induces B lymphocytes to produce immunoglobulin. Nature 1986; 324: 73-76.

18. Standiford JD, Kunkel SL, Basha MA, et al. Interleukin-8 gene expression by a pulmonary epithelial cell line; a model for cytokine networks in the lung. J Clin Invest 1990; 86: 1945-1953. 
19. Peveri P, Walz A, Dewald B, Baggiolini M. A novel neutrophil-activating factor produced by human mononuclear phagocytes. J Exp Med 1988; 167: 1547-1559.

20. Richman-Eisenstat JBY, Jorens PG, Hébert CA, Ueki I, Nadel JA. Interleukin-8: an important chemoattractant in sputum of patients with chronic inflammatory airway diseases. Am J Physiol 1993; 264 (Lung Cell Mol Physiol 8): L413-L418.

21. Vogel L, van Alphen L, Geluk F, et al. Quantitative flow cytometric analysis of opsonophagocytosis and killing of nonencapsulated Haemophilus influenzae by human polymorphonuelear leukocytes. Clin Microbiol Lab Immunol 1994; 1: 394-400.

22. Finkbeiner WE, Carrier SD, Teresi CE. Reverse transcription chain reaction (RT-PCR) phenotypic analysis of cell cultures of human tracheal epithelium, tracheobronchial glands, and lung carcinomas. Am J Cell Mol Biol 1993; 9: 547-556.

23. Van Schilfgaarde M, van Alphen L, Eijk PP, Everts V, Dankert J. Paracytosis of $H$. influenzae through cell layers of NCI-H292 lung epithelial cells. Infect Immun 1995; 63: 4729-4737.

24. Bergmeyer, HU. Methods of Enzymatic Analysis. Vol III. 3rd Edn. Germany, Verlag Weinheim, 1983; pp.126-133.
25. Mosmann T. Rapid colorimetric assay for cellular growth and survival: application to proliferation and cytotoxicity assays. J Immunol Methods 1983; 65: 55-63.

26. Helle M, Boeije L, de Groot E, de Vos A A, Aarden LA. Sensitive ELISA for interleukin-6. Detection of IL-6 in biological fluids: synovial fluids and sera. $J$ Immunol Methods 1991; 138: 47-56.

27. Hack CE, Hart M, Strack van Schijndel RJM, et al. Interleukin-8 in sepsis: relation to shock and inflammatory mediators. Infect Immun 1992; 60: 2835-2842.

28. Jennrich RI, Schluchter MD. Unbalanced repeatedmeasures models with structured covariance matrices. Biometrics 1986; 42: 805-820.

29. Wright SP. Adjusted P-values for simultaneous interference. Biometrics 1992; 48: 1005-1013.

30. Currie DC, Higgs E, Metcalfe S, Roberts DE, Cole PJ. Simple method of monitoring microbial load in chronic bronchial sepsis: pilot of reduction in colonising microbial load with antibiotics given intermittently and continuously. J Clin Pathol 1987; 40: 830-836.

31. Lugtenberg B, van Alphen L. Molecular architecture and functioning of the outer membrane of Escherichia coli and other Gram-negative bacteria. Biochim Biophys Acta 1983; 737: 51-115. 